\title{
Commentary in Honor of Peter C. Doherty
}

\author{
Robert Korngold
}

$\mathbf{I}$ HAVE HAD the good fortune in my scientific career to have been mentored by some great immunologists, but above all my experience in Peter C. Doherty's laboratory as a postdoctoral trainee at the Wistar Institute in Philadelphia left me with indelible impressions on how to balance the intensity of research with a decent measure of humility and devotion to friends and family. Having come out of a strong cellular immunology graduate program at the University of Pennsylvania in 1979 where I worked with Jonathan Sprent on graft-versushost disease immunobiology, I was eager to learn more about viral immunology and there seemed to be no better opportunity to do that than in Peter's laboratory. It was also highly convenient that the Wistar Institute was only a block away from where I had trained so I did not have to uproot my family, but the Wistar also had its own unique dynamic and environment that was clearly different from what I had previously been exposed. Under the long-term directorship of Hillary Koprowski, the institute had a long history of achievements and was strongly focused on virology and cancer immunology with many leading scientists in those fields, including Giorgio Trinchieri, Barbara Knowles, Walter Gerhard, Carlo Croce, Tad Wiktor, and Meenhard Herlyn, just to name a few. In addition, I was already friendly with many of the graduate students and postdocs who were working in various laboratories there.

Upon entering Peter's laboratory, I immediately got involved with several projects, the first of which was to investigate the influence of host thymocytes in the early reconstituting thymus of parental into F1 radiation chimeras and their capacity to generate cytotoxic responses to vaccinia virus. We found that host elements were surprisingly still active at 14 days postlethal irradiation, whereas donor thymocytes arising de novo from $\mathrm{T}$ cell-depleted bone marrow infusion became dominant by 21 days (1). Interestingly, the host thymocytes were resistant to depletion with antithymocyte serum at the time of chimera preparation. These findings helped to clarify previously confounding results concerning major histocompatibility complex (MHC)-restriction in parental into $\mathrm{F} 1$ radiation chimeras when thymocytes were tested at early serial time points.

Continuing on with $\mathrm{T}$ cell responses to vaccinia virus, we examined the relative frequencies of responsiveness between $\mathrm{H}-2 \mathrm{~K}^{\mathrm{k}}$ and $\mathrm{H}-2 \mathrm{D}^{\mathrm{b}}$ MHC restricted T cells at the site of pathology in intracerebrally vaccinia challenged $\mathrm{B} 10 \mathrm{~A}(2 \mathrm{R})$ $\mathrm{H}-2 \mathrm{~K}^{\mathrm{k}} \mathrm{D}^{\mathrm{b}}$ mice (2). Examining the cerebrospinal fluid exudate, we found that there was a hierarchical response strongly favoring $\mathrm{H}-2 \mathrm{~K}^{\mathrm{b}}$ restricted $\mathrm{T}$ cell responses, despite the fact that in $\mathrm{H}-2 \mathrm{~K}^{\mathrm{b}} \mathrm{D}^{\mathrm{b}}$ mice, there were excellent responses to $\mathrm{H}-2 \mathrm{D}^{\mathrm{b}}$ target cells. This suggested the phenomenon of immunodominance and influence of genetic elements such as Ir genes.
While at the Wistar, Peter was part of a program project focused on slow viruses and possible causes of multiple sclerosis (MS). Peter thus got me involved with a project that investigated localization of the physiological compartment controlling susceptibility to induction of acute experimental allergic encephalomyelitis, a murine model for MS. Hematopoietic radiation chimeras were prepared between the highly responsive SJL and low responder B10.S strains. Upon challenge with SJL mouse spinal cord homogenate ( $\mathrm{MSCH}$ ) preparations, high incidence of clinical disease was exhibited by B10.S $\rightarrow$ SJL chimeras but not by SJL $\rightarrow$ B10.S mice, suggesting that nonbone-marrowderived factors were influencing development of disease (3).

In the Fall of 1981, Peter accepted an offer to return to the John Curtin School of Medical Research in Canberra, Australia. In preparation for that move, Peter was instrumental in launching my own independent research career and that of my friend and colleague, Jack Bennink, a former graduate student of Peter and an expert in influenza virus, as we became junior faculty members of the Wistar and took over the leadership of Peter's existing grants. This was a tremendous opportunity and Jack and I shared Peter's old laboratory for 6 years before we both moved on to other institutions.

In closing, I am forever grateful to Peter for the opportunities and support that he gave me at a crucial time in my early career and for having the chance to work closely with one of the greatest immunologists of our time.

\section{Author Disclosure Statement}

No competing financial interests exist.

\section{References}

1. Korngold R, Bennink JR, and Doherty PC. Early dominance of irradiated host cells in the responder profiles of thymocytes from P leads to F1 radiation chimeras. J Immunol 1981;127:124-129.

2. Doherty PC, and Korngold R. Hierarchies of T cell responsiveness are reflected in the distribution of effector $\mathrm{T}$ cells in viral meningitis. Aust J Exp Biol Med Sci 1983;61 (Pt 4):471-475.

3. Korngold R, Feldman A, Rorke LB, Lublin FD, and Doherty PC. Acute experimental allergic encephalomyelitis in radiation bone marrow chimeras between high and low susceptible strains of mice. Immunogenetics 1986;24:309-315.

Address correspondence to:

Dr. Robert Korngold

Hackensack Meridian Health

Center for Discovery and Innovation 340 Kingsland Street

Nutley, NJ 07110

E-mail: robert.korngold@hmh-cdi.org

Hackensack Meridian Health, Center for Discovery and Innovation, Nutley, New Jersey.

(C) Robert Korngold, 2020; Published by Mary Ann Liebert, Inc. This Open Access article is distributed under the terms of the Creative Commons Attribution Noncommercial License (http://creativecommons.org/licenses/by-nc/4.0/) which permits any noncommercial use, distribution, and reproduction in any medium, provided the original author(s) and the source are cited. 